\title{
Effect of ground contact surface on dry matter losses and nutritional value of stored wrapped round bales
}

\author{
H Arelovich, H Laborde, M Torrea, FT McCollum \\ Departamento de Agronomia-CERZOS, Universidad Nacional del Sur, \\ CONICET-CIC, 8000 Bahia Blanca, Argentina
}

In subhumid Argentina hay from large round bales is used as supplemental feed for cattle. Most round bales are stored outdoors and unprotected. Dry matter (DM) and nutrient losses were reported to be significant, mainly in the area of full contact with the soil (Russell et al, 1990, Anim Feed Sci and Tech, 29, 131145). The objective of this study was to measure the changes in quantity and quality of alfalfa-grass hay (AG) and oat hay (OA) baled and stored in contact with different ground surfaces.

Nine bales of each species, wrapped with plastic twine were placed into storage on March 3, 1993 using a complete randomized design with three replications. Bales were placed in single rows spaced approximately $1.2 \mathrm{~m}$ apart on a sandy soil, with $1.5 \%$ slope. Individual bales were separated by at least 0.5 $m$ from each other. The three treatments were : 1) direct ground contact (DGC) ; 2) stored on a straw strip (7.0 kg DM/m² SS) and 3) stored on a soil platform raised $0.30 \mathrm{~m}$ over soil level by successive ploughing with a disk plough (SP). All bales were weighed on March 3 (Initial) and October 5, 1993 (Final), and sampled with a core sampler. Samples were taken from the upper portion of each bale throughout $0.30 \mathrm{~m}$ deep (U), and from the side throughout the core (S). Samples were analyzed for DM, crude protein (CP), neutral detergent fibre (NDF), acid detergent fibre and ash content.

In all treatments, DM losses were low, averaging 10.2 and $8.8 \%$ for $O A$ and $A P$, respectively. Storage method had no significant effect on the DM losses of OA and $A P$ round bales. In addition, all the quality parameters analyzed showed no significant differences due to treatments. Well drained sandy soil with a $1.5 \%$ slope, appears to be a reliable storage surface for round bales in subhumid Argentina.

Quality parameters on DM basis

\begin{tabular}{|c|c|c|c|c|c|c|c|c|c|c|}
\hline \multirow{3}{*}{$\begin{array}{l}\text { Storage } \\
\text { method }\end{array}$} & \multirow{3}{*}{$\begin{array}{l}\text { Bale } \\
\text { type }\end{array}$} & \multirow{3}{*}{$\begin{array}{l}\text { Dry matter } \\
\text { losses (\%) }\end{array}$} & \multicolumn{4}{|c|}{$\mathrm{CP}(\%)$} & \multicolumn{4}{|c|}{ NDF (\%) } \\
\hline & & & \multicolumn{2}{|c|}{ Initial } & \multicolumn{2}{|c|}{ Final } & \multicolumn{2}{|c|}{ Initial } & \multicolumn{2}{|c|}{ Final } \\
\hline & & & $U$ & $S$ & $U$ & $S$ & $\mathrm{U}$ & $S$ & $U$ & $S$ \\
\hline DGC & $O A$ & 12.56 & 5.4 & 5.5 & 5.6 & 5.6 & 71 & 71 & 72 & 70 \\
\hline SS & $O A$ & 6.32 & 5.6 & 5.5 & 5.6 & 5.3 & 72 & 71 & 72 & 72 \\
\hline SP & $O A$ & 11.68 & 5.9 & 5.2 & 5.4 & 5.6 & 73 & 70 & 72 & 74 \\
\hline DGC & $A G$ & 11.24 & 9.4 & 9.4 & 9.6 & 9.5 & 74 & 75 & 72 & 74 \\
\hline SS & $A G$ & 9.05 & 9.4 & 9.3 & 10.1 & 9.7 & 75 & 76 & 72 & 74 \\
\hline SP & $A G$ & 6.21 & 10.2 & 9.1 & 10.6 & 9.8 & 76 & 76 & 75 & 72 \\
\hline
\end{tabular}

